\title{
РЕФОРМУВАННЯ СТАРШОЇ ЛАНКИ ЗАГАЛЬНООСВІТНЬОЇ ШКОЛИ: ПРОГНОЗИ ТА СТАВЛЕННЯ ПЕДАГОГІВ, БАТЬКІВ ТА УЧНІВ
}

\begin{abstract}
Висвітлюється проблема готовності педагогів до перехідного періоду в освітньому реформуванні. Означено проблеми впровадження інноваційної моделі профільного навчання у старшій школі: підготовка до вибору профілю навчання; когнітивний дисонанс у вчителів, викликаний різними типами програм; не підготовлені до вибору подальшої стратегії навчання батьки учнів та самі учні. Визначено тенденції щодо прогнозів та ставлення до інноваційної моделі профільної старшої школи в групах батьків, учителів та учнів. Наведено результати опитування в цих трьох групах щодо впровадження 12-річного терміну навчання та опитування педагогів щодо профілізації старшої школи. Виявлені тенденції розділено на соціально спрямовані та психолого-педагогічні. 3'ясовано, що негативне або амбівалентне ставлення можна змінити в процесі суспільного обговорення, за допомогою методів створення позитивного іміджу освітньої реформи. Наголошено на актуальності подальшого суспільного діалогу щодо питань профільної орієнтації, допрофільної підготовки, перепідготовки та підвищення кваліфікації педагогів, а головне - змісту профільної підготовки.

Ключові слова: профільна старша школа, психологічна готовність педагогів, прогнози та ставлення до освітньої реформи.
\end{abstract}

Постановка проблеми. Утілення ідей реформування шкільної освіти завжди супроводжується неоднозначною реакцією з боку суспільства. Як і будь-який соціально значущий проект, що зачіпає інтереси більшості громадян, освітня реформа має певні ризики. Зокрема, завдання переходу на нову модель профілізації старшої школи зумовлює необхідність розв'язання низки проблем, серед яких такі:

1) проблема підготовки до вибору профілю навчання - пов'язана 3 неготовністю більшості старшокласників на початку навчання в старшій школі до ефективного формування індивідуальної освітньої траєкторії розвитку, що зумовлює необхідність зовнішнього контролю за індивідуалізацією навчального процесу;

2) проблема неготовності багатьох педагогів працювати за програмами різного типу відповідно до вибору учня;

3) проблема наступності між профільним навчанням у старшій школі та професійною освітою у вищих навчальних закладах 3-4 рівня акредитації;

4) проблема неготовності значної кількості майбутніх старшокласників та батьків учнів до вибору освітньої стратегії, що стає схо- 
динкою для подальшого професійного вибору і може викликати необхідність переходу до іншого навчального закладу.

Аналіз останніх досліджень та публікащій. Завдяки низці досліджень виявлено специфічні для вчителів старшої школи професійні завдання в системі профільного навчання, які викликають у них найбільші сумніви: проектування освітнього процесу, спрямованого на індивідуалізацію навчання; розроблення і реалізація курсів за вибором допрофільної підготовки та профільного навчання; застосування методів i технологій навчання, які сприяють побудові індивідуальної освітньої траєкторії учня; проектування програми професійного саморозвитку вчителя в контексті обраного профілю [1-9].

У стратегічному сенсі становлення початкової професійної компетентності випускників профільної старшої школи сприятиме усвідомленому професійному самовизначенню старшокласників як соціально значущому завданню. Інший аспект у впровадженні інноваційної моделі старшої школи - докорінна модернізація системи шкільної освіти в напрямі індивідуалізації та побудови кар'єри кожним випускником. Отже, саме ідеї нової профілізації покликані стати важелем модернізації та корекції змісту навчання в старшій ланці школи.

Зауважимо, що освітні системи багатьох країн уже мають позитивний досвід апробації організаційних та методичних моделей профільної старшої школи [10; 11]. Узагальнення представлених у різних джерелах основних ідей зарубіжного досвіду організації профільного навчання в Німеччині, Данії, Швеції, США, Канаді, Франції, Італії, Великобританії, країнах Східної Європи, а також у Китаї та Японії дає підстави говорити про таке:

1) кількість обов'язкових навчальних предметів порівняно 3 основною школою зменшується, в обов'язковому порядку мають вивчатися природничі науки, іноземні мови, математика, рідна словесність, фізична культура;

2) старша профільна школа виокремлюється в самостійний вид освітнього закладу;

3) кількість профілів і навчальних курсів у старшій ланці школи за кордоном постійно скорочується, водночас зростає число обов'язкових предметів і курсів, застосовується та чи інша система зовнішнього незалежного оцінювання;

4) у багатьох країнах сформовано систему допрофільної підготовки, у тому числі елективні курси, різні форми інформаційної роботи й профільної орієнтації;

5) існує система підготовки та перепідготовки вчителя профільного навчання 3 предметно-профільною спеціалізацією, консультанта служби "Гайденс" або іншого фахівця за психологічною спеціалізацією, що здійснює супровід профільного навчання (консультативна служба 
“Гайденс" діє при будь-якій середній школі США і має п’ять служб: інвентарну, службу інформації, службу консультування, службу влаштування, службу контролю);

6) при моделюванні змісту освіти в старшій школі використовують: а) трикомпонентний підхід до конструювання структури і змісту профілів різних типів, включаючи курси базового, профільного та елективного типу (Польща, Франція); б) навчання на основі індивідуального навчального плану (Великобританія, США); в) багатопрофільні освітні установи (Франція, Польща, Швеція, Норвегія);

7) інформаційне забезпечення і соціально-психологічний супровід старшокласників здійснюється у вигляді тьюторської підтримки учнів (Великобританія, США); соціального партнерства та мережевої співпраці в системі профільного навчання (США); функціонування ресурсних центрів профільного навчання (США) $[1 ; 3 ; 10 ; 11]$.

Meта cmammi: визначити тенденції щодо прогнозів та ставлення до інноваційної моделі профільної старшої школи в різних групах (батьків, вчителів та учнів), що дасть змогу не лише оцінити уявлення про освітню реформу в суспільній свідомості, а й запропонувати необхідні корективи в ході впровадження зазначеної моделі. Дослідження проводиться в межах всеукраїнського експерименту “Формування позитивної громадської думки щодо освітніх інновацій”, який було започатковано в лютому 2016 р. Одним із завдань експерименту є впровадження системи роботи, орієнтованої на профілізацію старшої школи.

Виклад основного матеріалу. Основною методологічною і психолого-педагогічною проблемою впровадження ідей профільної освіти в старшій школі $\epsilon$ значне зменшення частки інваріантного компонента змісту освіти порівняно з основною школою і зростання обсягу варіативного шкільного компонента, за рахунок якого реалізується профільна диференціація змісту освіти. Така перебудова змісту освіти потрібна для того, щоб у суспільній свідомості сформувався позитивний імідж освітньої реформи. Основні зацікавлені групи, яких зачіпають різні аспекти реформи, - це вчителі, учні та батьки учнів. Узагальнення проблематики психологічної готовності педагогів до інноваційних змін у старшій школі дає підстави для виокремлення таких аспектів: 1 ) готовність учителя до посилення конкурентоспроможності в педагогічній спільноті, адже затребуваною стає гнучкість поведінки та справжня педагогічна творчість; 2 ) зростання тривоги 3 приводу майбутньої перебудови змісту навчання, у результаті чого частина вчителів може втратити роботу.

Неспроможність частини педагогів вийти за межі встановлених форм освітнього простору спричинена постанням нових завдань у зв'язку з освітньою реформою:

1) учитель має бути готовим до використання нових методів та засобів визначення динаміки просування учнів у навчальному процесі 
з урахуванням індивідуальної освітньої траєкторії, різних критеріїв в оцінюванні освітніх досягнень старшокласників шляхом укладання їхнього особистісного рейтингу;

2) учитель має бути готовим до принципово нової логіки викладання навчального предмета, виходячи з варіанта освітнього профілю, використання системної логіки і міжпредметних компетенцій;

3) зростає значення готовності до використання дистанційних форм навчання, а отже, значущість інформаційних технологій у підготовці вчителя.

Для виявлення прогнозів та ставлення респондентів до інноваційної моделі старшої школи на базі двох загальноосвітніх шкіл м. Кривого Рогу було сформовано вибірку із 150 осіб. 3 них: 80 жінки, 70 - чоловіки; вік респондентів - від 15 до 59 років; дорослі 100 осіб (співвідношення вчителів та батьків 50:50), старшокласники 50 осіб. Проведено опитування (2016-2017 н.р.) за двома анкетами (анкети затверджено в лабораторії соціально-психологічних технологій ІСПП НАПН України). Під час першого опитування виявлялося загальне оцінювання різних аспектів упровадження 12-річного навчання серед дорослих та учнів. Вибірка була такою: “дорослі” (вчителі та батьки учнів) - 84 особи, “старшокласники” - 88 осіб.

Проаналізуймо окремі тенденції у прогнозах та ставленні вчителів, батьків та старшокласників щодо початку реформування.

1. Ставлення до перспективи запровадження в загальноосвітніх школах 12-річного терміну навчання: відповіді розподілені приблизно однаково між трьома варіантами. Відповідно, позитивне ставлення 32\%, негативне - 34\%, “важко відповісти” - 32\% від загальної кількості респондентів.

2. Ставлення до самої ідеї оновлення системи профільного навчання в старшій школі у більшості респондентів позитивне, хоча у відповідях 20\% респондентів помітна невизначеність.

3. Прогноз вірогідності підвищення якості освіти внаслідок запровадження в загальноосвітніх школах 12-річного терміну навчання висвітлює протилежні позиції респондентів: 60\% респондентів вважають, що це “однозначно підвищить якість освіти”, тоді як 40\% вважають, що “не змінить якість освіти”.

4. На брак особистої зацікавленості в реформуванні середньої освіти в Україні вказали 14\% респондентів, а 20\% не можуть визначитися $з$ відповіддю. Вселяє певний оптимізм те, що 66\% опитаних відмітили особисту зацікавленість в освітній реформі: на тлі падіння інтересу та віри населення в ефективність реформ такий відсоток видається хорошим результатом.

Подальшим завданням дослідження було виявлення специфіки прогнозів та ставлення до освітньої реформи різних груп респондентів (табл.; рис. 1-4). 
Таблиия

Розподіл оцінок ставлення респондентів до освітньої реформи (\%)

\begin{tabular}{|c|c|c|c|c|c|c|}
\hline \multirow[b]{2}{*}{$\begin{array}{l}\text { Прогнози та ставлення } \\
\text { до освітньої реформи }\end{array}$} & \multicolumn{3}{|c|}{$\begin{array}{c}\text { Учителі } \\
\text { та батьки учнів }\end{array}$} & \multicolumn{3}{|c|}{$\begin{array}{l}\text { Старшоклас- } \\
\text { ники }\end{array}$} \\
\hline & 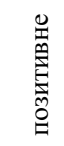 & 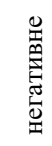 & 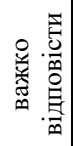 & 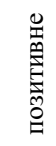 & 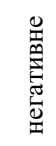 & 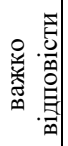 \\
\hline $\begin{array}{l}\text { 1. Показники ставлення до реформи } \\
\text { старшої ланки школи }\end{array}$ & 50 & 39 & 11 & 28 & 62 & 12 \\
\hline $\begin{array}{l}\text { 2. Ставлення до змін у моделі профільної } \\
\text { старшої школи }\end{array}$ & 100 & 0 & 0 & 88 & 4 & 8 \\
\hline $\begin{array}{l}\text { 3. Прогноз щодо підвищення якості освіти } \\
\text { в реформованій школі }\end{array}$ & 44 & 0 & 56 & 34 & 42 & 24 \\
\hline $\begin{array}{l}\text { 4. Особистісна зацікавленість респондентів } \\
\text { у реформуванні школи }\end{array}$ & 56 & 5 & 39 & 42 & 18 & 40 \\
\hline $\begin{array}{l}\text { 5. Оцінка перспективи доступності якісної } \\
\text { освіти в реформованій школі }\end{array}$ & 67 & 22 & 11 & 28 & 62 & 10 \\
\hline $\begin{array}{l}\text { 6. Оцінка своєчасності реформування } \\
\text { школи та перспектив її фінансування }\end{array}$ & 50 & 22 & 28 & 54 & 20 & 26 \\
\hline $\begin{array}{l}\text { 7. Прогноз вірогідності позитивних змін } \\
\text { у навчальному процесі в старшій ланці } \\
\text { школи }\end{array}$ & 6 & 61 & 33 & 40 & 48 & 12 \\
\hline $\begin{array}{l}\text { 8. Прогноз доброчесності та прозорості вибо- } \\
\text { ру випускників щодо можливості продов- } \\
\text { жити освіту у вищому навчальному закладі }\end{array}$ & 17 & 39 & 44 & 38 & 36 & 26 \\
\hline
\end{tabular}

Порівняно з дорослими старшокласники більш скептично ставляться до перспективи запровадження 12-річного терміну навчання: $62 \%$ негативних оцінок проти $39 \%$ у дорослих, позитивне ставлення у $50 \%$ дорослих і тільки у $28 \%$ старшокласників (див. рис. 1 ).

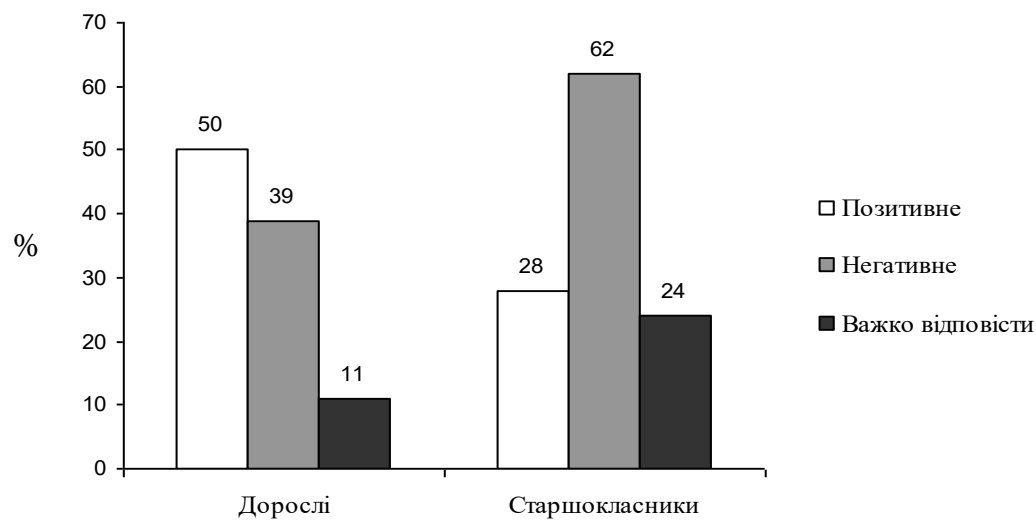

Puc. 1. Показники ставлення до реформи старшої ланки школи (\%) 
Старшокласники негативно оцінюють перспективу або не можуть визначитися щодо можливості підвищення якості середньої освіти внаслідок запровадження у школах 12-річного терміну навчання. Серед старшокласників $42 \%$ демонструють негативне ставлення до цього пункту, а $24 \%$ не визначилися. Серед педагогів та батьків 56\% опитаних не визначилися, але у них немає негативного ставлення (див. рис. 2).

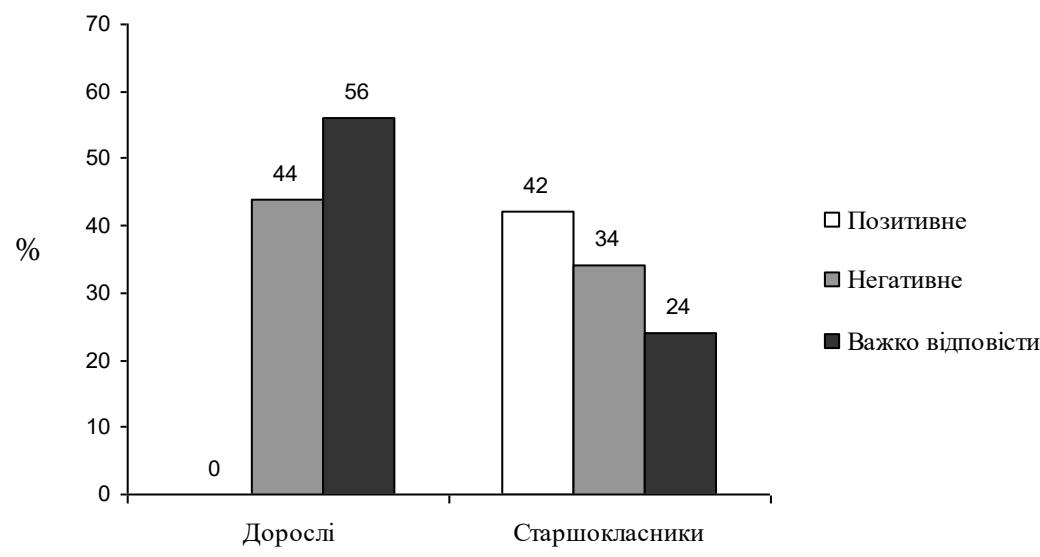

Рис. 2. Прогноз щодо підвищення якості освіти

в реформованій школі (\%)

Серед старшокласників порівняно $з$ дорослими менша частка тих, хто відчуває особисту зацікавленість у реформуванні середньої освіти в Україні (42\% проти 56\%).

Серед старшокласників більше, ніж серед дорослих, тих, хто дає негативний прогноз щодо впровадження 12-річного терміну навчання як можливості доступу до якісної освіти більшій кількості молоді: $62 \%$ негативних відповідей проти $22 \%$ у дорослих (див. рис. 3 ).

Майже однакову позицію займають зазначені групи респондентів щодо збільшення терміну шкільного навчання за європейським зразком, вважаючи, що таке збільшення не виправдовує себе в українських реаліях, $є$ недоречним і фінансово невигідним. Так, позитивний прогноз висловлюють 50\% дорослих та 54\% старшокласників. Частки скептиків і таких, що вагаються у порівнюваних групах, є приблизно однаковими.

Старшокласники більше, ніж дорослі, сподіваються на те, що додатковий 12-й рік навчання дасть змогу збалансувати програми i розвантажити учнів, позбавивши їх громіздких домашніх завдань та великої кількості уроків (40\% позитивних відповідей у старшокласників проти 6\% у дорослих). 


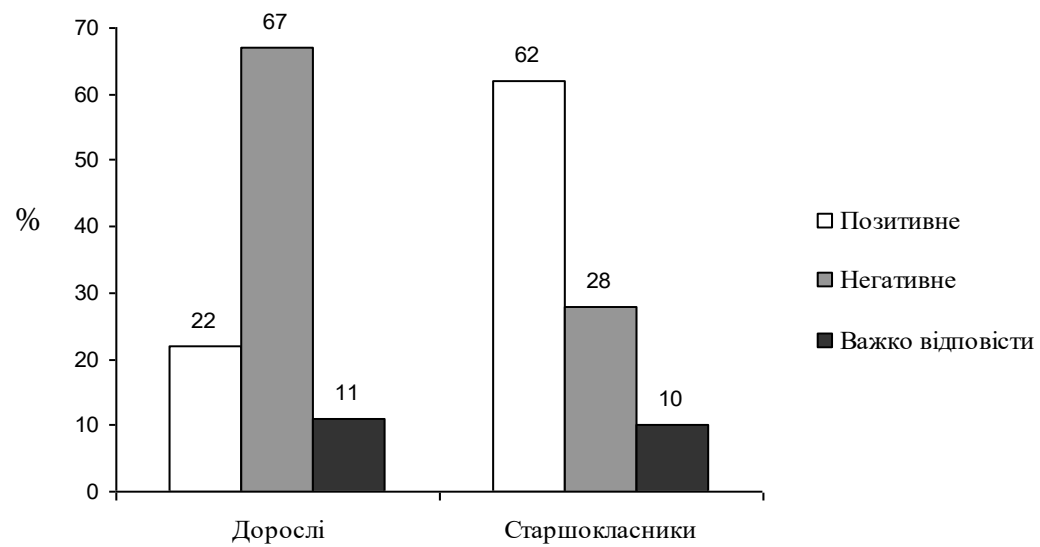

Puc. 3. Перспективи доступності якісної освіти в реформованій школі (\%)

Учнівська молодь більше сподівається на те, що із запровадженням 12-річного навчання багато корупційних складових (вступні внески, конкурсний відбір, підготовчі курси) залишаться в минулому: $38 \%$ позитивних відповідей у старшоклассників проти $17 \%$ у дорослих) (див. рис. 4).

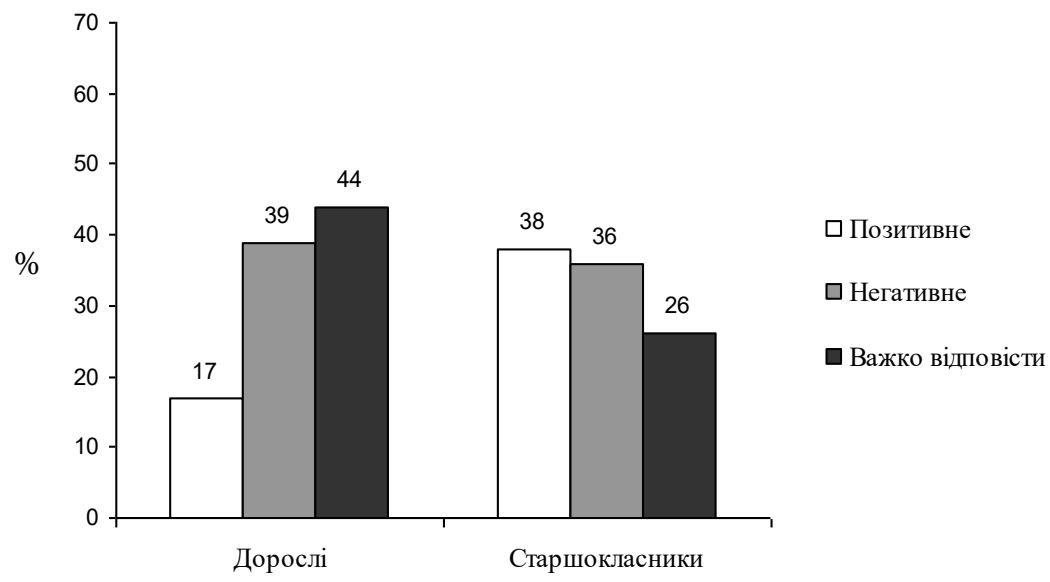

Puc. 4. Прогноз доброчесності та прозорості роботи освітнього закладу щодо можливості випускників продовжити освіту

У другому опитуванні брали участь тільки вчителі (60 осіб). Активне осмислення інновацій у старшій школі триває: бурхливо відбу- 
вається обговорення змін у профільному навчанні в старшій школі. Ідея навчальних профілів не $\epsilon$ новою в українській освітній системі, проте вона нібито “додавалася” до єдиного блоку обов'язкових предметів, число яких зростало.

На сьогодні ідея полягає у значній зміні моделі навчального плану в старшій школі. Це, зокрема, заміна чотирьох предметів природничо-наукового циклу єдиним світоглядним курсом «Людина i природа» для класів суспільно-гуманітарного профілю. На основі положень методичних вказівок до складання профільного навчального плану в старших класах автором розроблено анкету для виявлення ставлення та очікувань педагогів основної та старшої ланок школи. Було здійснено аналіз відповідних нормативних документів МОН України та публікацій дискусійного характеру. Виявлено проблемні аспекти методологічного та методичного характеру щодо інноваційної моделі старшої школи, які було включено до анкети.

Під час проведення другого анкетування виявлено такі основні тенденції:

- ставлення педагогів до переліку дисциплін інваріантного (обов'язкового) складника навчального плану в переважній більшості $\epsilon$ позитивним (70\%), у $30 \%$ респондентів - скоріше негативне і негативне;

- ідею про те, що посилення профільного типу навчання в старших класах забезпечить освітні потреби старшокласників, зумовлені орієнтацією на майбутню професію та їхню життєву перспективу, позитивно оцінюють $70 \%$ респондентів, а $30 \%$ - скоріше негативно;

- стан розв'язання проблеми надмірного ускладнення термінології програм, якою мають користуватися вчителі у викладанні дисциплін у старшій школі, оцінили позитивно близько $10 \%$ респондентів, скоріше негативно - 80\%, негативне ставлення виявили $10 \%$ респондентів. Такий результат засвідчує наявність суттєвих методологічних та методичних проблем, що постають перед педагогічною спільнотою у зв'язку з перебудовою навчально-виховного процесу в старшій школі;

- можлива заміна в 10-11-х класах суспільно-гуманітарного профілю фізики, географії, хімії та біології на єдиний світоглядний курс “Людина і природа" викликала суперечливе ставлення. Відповідно $50 \%$ педагогів висловили безумовно позитивне і позитивне ставлення, тоді як 50\% - скоріше негативне і негативне. Крайні позиції займають по $10 \%$ педагогів;

- педагоги основної та старшої школи активно використовували для ознайомлення з різними аспектами реформування старшої школи сайт ЕdЕга; відповідно $80 \%$ із них позитивно оцінюють ресурси сайту, тоді як $20 \%$ опитаних не зовсім задоволені можливостями інформаційних ресурсів; 
- зміни в системі оцінювання та перевірки навчальних досягнень учнів на різних когнітивних рівнях методично забезпеченим вважають $30 \%$ опитаних педагогів, а частково забезпеченим - 70\%;

- практику оцінювання за різними критеріями (сформованість ключових і предметних компетентностей, способів навчальної діяльності, досвід творчої діяльності) учнів старшої школи $60 \%$ опитаних педагогів оцінюють скоріше негативно, мотивуючи це тим, що наразі немає чітких показників для такого оцінювання;

- ставлення педагогів до переліку навчальних предметів вибірково-обов'язкового циклу таке: у $10 \%$ - безумовно позитивне, у $70 \%$ позитивне, у $10 \%$ - нейтральне, у 10\% - негативне;

- ставлення до можливості навчального закладу самостійно визначати спецкурси та факультативи за профілем закладу у $20 \%$ педагогів безумовно позитивне, у $80 \%$ - позитивне; отже, позитивне ставлення виявляють усі респонденти;

- ставлення до сукупності змін навчального плану для профільного навчання в 10-11-х класах безумовно позитивне у $10 \%$ педагогів, позитивне - у $80 \%$, інші 10\% педагогів дали негативну оцінку.

Висновки. У результаті вивчення ставлення педагогів, батьків та учнів до впровадження 12-річного навчання виявлено, що дорослі (як педагоги, так і батьки) більш позитивно порівняно з учнями оцінюють цю інновацію.

Ставлення педагогів до різних аспектів профілізації старшої школи переважно позитивне, хоча існують методологічні та методичні проблеми щодо інноваційної моделі старшої школи. Перебудова освітньої діяльності загальноосвітніх навчальних закладів у напрямку профілізації навчання в старшій школі у світлі реформування освіти потребує вирішення низки системних завдань. Зміни, що пропонуються в офіційних документах, викликають неоднозначну реакцію педагогічної спільноти, батьків та учнів. Упровадження моделі трирічної профільної старшої школи ще попереду, проте зміни відбуваються вже сьогодні. Актуальними стають організаційно-методичні заходи та психологічний супровід забезпечення допрофільної підготовки. Не менш гостро стоїть питання організації перепідготовки педагогів. У ході дослідження виявлено суттєві відмінності прогнозів та ставлення до інноваційних змін у старшій школі серед дорослих (педагоги, батьки) та старшокласників. Враховуючи те, що деякі питання реформування старшокласники оцінили більш негативно, ніж дорослі, вважаємо, що для формування позитивного іміджу реформ слід звернути увагу саме на випускників шкіл, студентів та молодих спеціалістів. Старт інноваційної моделі профільної старшої школи заплановано на 2027 рік, отже, саме для цієї вікової когорти як майбутніх батьків питання вступу дитини до старшої профільної школи стає актуальним. 
Виявлені тенденції щодо прогнозів та ставлень педагогів, батьків та старшокласників можна розділити на соціально спрямовані і психолого-педагогічні. Визначено, що зміни негативного або амбівалентного ставлення на позитивне відбуваються в процесі суспільного обговорення, використання методів створення позитивного іміджу освітньої реформи. Актуальність подальшого суспільного діалогу щодо питань профільної орієнтації, допрофільної підготовки, перепідготовки та підвищення кваліфікації педагогів, а головне - змісту профільної підготовки є безумовною.

Перспективу подальших досліджень ми вбачаємо у впровадженні соціально-психологічних технологій та моделі психолого-педагогічного супроводу реформи школи в контексті перебудови загальноосвітньої підготовки учнівської молоді в профільній старшій школі.

\section{Лimepamypa}

1. Воронина Е. В. Профильное обучение: модели организации, управления и методического сопровождение / Е. В. Воронина. - Москва : Знание, 2006. $251 \mathrm{c}$.

2. Закон України про освіту від 05.09.2017, № 2145-VIII [Електронний ресурс] // Відомості Верховної Ради. - 2017. - № 38-39. - Ст. 380. Режим доступу : http://search.ligazakon.ua/l_doc2.nsf/link1/T172145.html

3. Касьянова О. М. Кваліметрична модель оцінки готовності школи до впровадження профільного навчання / О. М. Касьянова // Управління школою. 2004. - № 19-21. - C. 4.

4. Кравиов С. С. Профильное обучение: теория и практика : [монография]/ С. С. Кравцов. - Москва : Готика, 2007. -295 с.

5. Мельник О.В. Принцип активного професійного орієнтування учнів / О. В. Мельник // Теоретико-методичні проблеми виховання дітей та учнівської молоді : [зб. наук. праць]. - Кам'янець-Подільский : Вид. Зволейко Д. Г, 2009. - Вип. 13. - Кн. 2. - С. 299-307.

6. Москалик $Г$. Ф. Організація проблеми профільного навчання в сучасному освітньому закладі: регіональний аспект / Г. Ф. Москалик // Імідж сучасного педагога : наук.-практ. освіт.-популяр. журн. - 2005. - Вип. 1-2 (50-51). C. 34-38.

7. Москалик Г. Ф. Профілізація навчально-виховного процесу в загальноосвітній школі: регіональний аспект / Г. Ф. Москалик // Імідж сучасного педагога : наук.-практ. освіт.-популяр. журн. - 2005. - Вип. 3-4 (52-53). C. 21-23.

8. Серпионова Е. И. Психологические различия учащихся профильных классов / Е. И. Серпионова // Профильная школа. - 2009. - № 6(39). - С. $43-47$.

9. Сикорская Г.А. Профильное обучение старшеклассников в условиях модернизации образования : [монография] / Г. А. Сикорская. - Ниж. Новгород : ВГИПУ, 2009. $-289 \mathrm{c}$.

10. Соловйов В. Ф. Допрофесійна підготовка в системі "загальноосвітня школа професійний ліцей” : монографія / В. Ф. Соловйов ; за ред. А. В. Литвина. Львів : Сполом, 2014. - 256 с. 
11. Филатова Л. О. Профильное обучение в зарубежных странах / Л. О. Филатова // Экономический вестник Ростовского государственного университета. - 2005. - Т. 3. - № 1. - С. 144-158.

12. The effects of delay in gtracking in secondary school: evidence from the 1999 education reformin Poland / Jakubowski M. et al. // Education Economics. 2016. - Vol. 24. - №. 6. - P. 557-572.

\section{References}

1. Voronina, E. V. (2006). Profilnoye obucheniye: modeli organizatsii, upravleniya $i$ metodicheskogo soprovozhdeniya [Profile training: models of organization, management and method, support]. Moscow: Znaniye Publ. (rus).

2. Zakon Ukrainy pro osvitu vid 05.09.2017, № 2145-VIII (2017). [The Low of Ukraine on Education of 05.09.2017, № 2145-VIII]. Vidomosti Verkhovnoi Rady [Statements of the Supreme Council of Ukraine], № 38-39, Art. 380 (ukr).

3. Kasianova, O. M. (2004). Kvalimetrychna model otsinky hotovnosti shkoly do vprovadzhennia profilnoho navchannia [Qualitative model of the readiness of the school to implement the profile education]. Upravlinnia shkoloiu [School management], 19-21, 4 (ukr).

4. Kravtsov, S. S. (2007). Profilnoye obucheniye: teoriya i praktika [Profile training: theory and practice]. Moskow: Gotika Publ. (rus).

5. Melnyk, O. V. (2009). Pryntsyp aktyvnoho profesiinoho oriientuvannia uchniv [Principle of active professional orientation of students]. Teoretyko-metodychni problemy vykhovannia ditei ta uchnivskoi molodi [Theoretical and methodological problems of education of children and pupils' youth]. Kamianets-Podilskyi (ukr).

6. Moskalyk, H. F. (2005). Orhanizatsiia problemy profilnoho navchannia v suchasnomu osvitnomu zakladi: rehionalnyi aspekt [Profiling of the educational process in a secondary school: a regional aspect]. Imidzh suchasnoho pedahoha: naukovo-praktychnyi osvitno-populiarnyi zhurnal [The image of a modern educator: a scientific and practical educational and popular magazine], 1-2 (50-51), 34-38 (ukr).

7. Moskalyk, H. F. (2005). Profilizatsiia navchalno-vykhovnoho protsesu v zahalnoosvitnii shkoli: rehionalnyi aspekt [Profiling of the educational process in a secondary school: a regional aspect]. Imidzh suchasnoho pedahoha: naukovopraktychnyi osvitno-populiarnyi zhurnal [The image of a modern educator: a scientific and practical educational and popular magazine], 3-4 (52-53), 21-23 (ukr).

8. Serpionova, Ye. I. (2009). Psikhologicheskiye razlichiya uchashchikhsya profilnykh klassov [Psychological differences between students in specialized classes]. Profilnaya shkola [Profile School], 6(39), 43-47 (rus).

9. Sikorskaya, G. A. (2009). Profilnoye obucheniye starsheklassnikov v usloviyakh modernizatsii obrazovaniya [Specialized training of senior students in the conditions of modernization of education]. Nizhny Novgorod (rus).

10. Soloviov, V. F. (2014). Doprofesiina pidhotovka v systemi "zahalnoosvitnia shkola - profesiinyi litsei" [Preprofessional education in the system "high school - vocational education"]. Lviv: Spolom Publ. (ukr). 
11. Filatova, L. O. (2005). Profilnoye obucheniye v zarubezhnykh stranakh [Specialized training in foreign countries]. Ekonomicheskiy vestnik Rostovskogo gosudarstvennogo universiteta [Economic Bulletin of Rostov State University], 3 (1), 144-158 (rus).

12. Jakubowski, M. et al. (2016). The effects of delay in gtracking in secondary school: evidence from the 1999 education reformin Poland. Education Economics, Vol. 24, № 6, pp. 557-572.

\section{Shestopalova O. P. Senior Secondary School Reforming: Forecasts and Attitudes of Teachers, Parents and Pupils}

The article highlights the problem of teachers' readiness before the transition period in education reform. The profiling model contains such problems: 1) the problem of preparation for the choice of the profile of education, 2) cognitive dissonance of teachers with regard to programs of different types, 3) the problem of continuity, unprepared parents of students to choose the education strategy. The author sets the goal to identify trends in the forecasts and the attitude towards the innovative model of the profile high school in different social groups which will allow not only to appreciate the idea of education reform in the public consciousness, but also to offer the necessary adjustments while implementing the model. It is analysed in the article the specificity of the forecasts and the system of attitude towards the innovative model of the profile in high school. The results presented predictions of $\mathrm{SS}$ in the implementation of profiling in grades $10-12$. The study revealed significant differences in predictions and attitudes towards innovative changes in the upper school in the adult group (primary and secondary school teachers and parents of students) and in the youth group (senior pupils). The revealed trends in the forecasts and attitudes of teachers, parents of students and senior pupils can be divided into socially-oriented, psychological and pedagogical. It is devoted that changes in negative, ambivalent forecasts and attitudes occur in the process of social discussion using methods for creating a positive image of education reform. The urgency of further social dialogue on questions of profile orientation, pre-professional training, retraining and professional development of teachers, and the main content of profile training is unconditional.

Key words: profile senior school, psychological readiness of teachers, forecasts and attitude to the ideas of education reform.

(C) Шестопалова О. П. 